
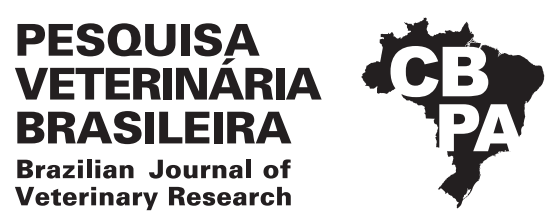

Pesq. Vet. Bras. 39(4):263-270, April 2019 DOI: 10.1590/1678-5150-PVB-5861

ISSN 0100-736X (Print) ISSN 1678-5150 (Online)

\title{
A new experimental model of intrinsic denervation in ileum from wistar rats through intramural microinjections of benzalkonium chloride ${ }^{1}$
}

\author{
Juliana O. Ribeiro ${ }^{3 *}$ (D), Marília G.P.A. Ferreira ${ }^{3}$, Isabela C.S. Marques², \\ Carolina Alvarenga ${ }^{2}$, Andrigo B. Nardi ${ }^{3}$, Sérgio B. Garcia ${ }^{2}$, Gabriel Luiz Montanhim ${ }^{3}$ \\ and Paola C. Moraes ${ }^{3}$
}

\begin{abstract}
Ribeiro J.O., Ferreira M.G.P.A., Marques I.C.S., Alvarenga C., Nardi A.B., Garcia S.B., Montanhim G.L. \& Moraes P.C. 2019. A new experimental model of intrinsic denervation in ileum from wistar rats through intramural microinjections of benzalkonium chloride. Pesquisa Veterinária Brasileira 39(4):263-270. Departamento de Patologia, Faculdade de Medicina de Ribeirão Preto, Universidade de São Paulo, Rua Ten. Catão Roxo 2398, Vila Monte Alegre, Ribeirão Preto, SP 14051-140, Brazil. E-mail: juliana.oribeiro@yahoo.com.br

Extensive literature is available about the intrinsic denervation of segments of the digestive tube through the application of CB in the serosa of the viscera. However, this technique has some disadvantages like causing peritonitis, flanges and high mortality, limiting its use in humans. The aim of the present study was to evaluate the feasibility of benzalkonium chloride (CB) to induce intrinsic chemical denervation, through applications of CB in the intramural ileum of wistar rats, as well as deepen the knowledge about the evolution of neuronal injury caused in the process. We used 40 rats, divided into two groups (control-GC and benzalkonium-GB) of 20 animals each, divided into four sub-groups according to the time of postoperative assessment of 24, 48 hours, 30 and 90 days. The animals were submitted to intramural microinjections of sterile saline solution $0.9 \%$ (GC) or benzalkonium chloride (GB) in ileal portion, and subsequent histopathological analysis and immunohistochemistry for evaluation of neuronal injury. A significant decrease $(p<0.05)$ was found of the neuronal myenteric count over time in groups, GB3, GB4 and GB2. The specific positive immunolabeling for $\mathrm{H} 2 \mathrm{AX}$ and Caspase- 3 confirmed the results obtained in the histopathological evaluation, denoting the ignition of irreversible cell injury in 24 hours, evolving into neuronal apoptosis in 48 hours after application of the CB $0.3 \%$. Under the conditions in which this work was conducted, it can be concluded that the application of CB $0.3 \%$ by means of microinjections intramural in the ileal wall is able to induce intrinsic chemical denervation of the diverticulum of wistar rats and that the main mechanism of neuronal death is induction of apoptosis.
\end{abstract}

INDEX TERMS: Experimental model, intrinsic denervation, ileum, wistar rats, intramural microinjections, benzalkonium chloride, apoptosis, myenteric plexus, neurons myenterics, short bowel syndrome, small intestine, rodents, clinics.

RESUMO.- [Um novo modelo experimental de desnervação intrínseca em íleo de ratos wistar através de micro injeções intramurais de cloreto de benzalcônio.] Existe

\footnotetext{
${ }^{1}$ Received on July 31, 2018.

Accepted for publication on November 26, 2018.

${ }^{2}$ Departamento de Patologia, Faculdade de Medicina de Ribeirão Preto, Universidade de São Paulo (USP), Rua Ten. Catão Roxo 2398, Vila Monte Alegre, Ribeirão Preto, SP 14051-140, Brazil.

${ }^{3}$ Departamento de Veterinária Clínica e Cirurgia, Faculdade de Ciências Agrárias e Veterinárias (FCAV), Universidade Estadual Paulista (Unesp), Campus Jaboticabal, Via acesso Prof. Paulo Donato Castelane s/n, Jaboticabal, SP 14884-900, Brazil. *Corresponding author: juliana.oribeiro@yahoo.com.br
}

vasta literatura sobre a desnervação intrínseca de segmentos do tubo digestório através da aplicação de CB na serosa da víscera. Entretanto, essa técnica tem a desvantagem de causar peritonite, formação de bridas e alta mortalidade, não sendo factível para eventuais utilizações em humanos. $\mathrm{O}$ objetivo do presente estudo foi avaliar a viabilidade do Cloreto de benzalcônio (CB) induzir desnervação química intrínseca, por meio de aplicações intramurais em íleo de ratos wistar, além de aprofundar o conhecimento sobre a evolução da lesão neuronal causada neste processo. Foram utilizados 40 ratos, distribuídos em dois grupos (controle- GC e benzalcônio- GB) de 20 animais cada, subdivididos em quatro 
subgrupos de acordo com o tempo de avaliação pós-operatória de 24, 48 horas, 30 e 90 dias. Os animais foram submetidos à microinjeções intramurais de solução salina estéril 0,9\% (GC) ou de cloreto de benzalcônio (GB) em porção ileal, e posterior análise histopatológica e imuno-histoquímica, para avaliação da lesão neuronal. Houve diminuição significativa $(p<0,05)$ na contagem neuronal mientérica ao longo do tempo nos grupos GB2, GB3 e GB4. A imunomarcação específica positiva para H2AX e Caspase-3 confirmou os resultados obtidos na avaliação histopatológica, denotando início da lesão celular irreversível em 24 horas, evoluindo para apoptose neuronal em 48 horas após a aplicação do CB 0,3\%. Nas condições em que este trabalho foi conduzido, é possível concluir que a aplicação de CB 0,3\% por meio de microinjeções intramurais na parede ileal é capaz de induzir desnervação química intrínseca da porção ileal de ratos wistar e que o principal mecanismo de morte neuronal é a indução de apoptose.

TERMOS DE INDEXAÇÃO: Modelo experimental, desnervação intrínseca, íleo, ratos wistar, micro injeção intramural, cloreto de benzalcônio, apoptose, desnervação, neurônios mientéricos, síndrome do intestino curto, plexo mientérico, roedores, clínica.

\section{INTRODUCTION}

Chemical denervation by benzalkonium chloride as an experimental model of the digestive tube has been studied in different ways in the pathophysiology enteric coated, for example, for studies of the role of the enteric nervous system in proliferation mucosal epithelial cell and control of peristalsis (Zucoloto et al. 1991, Garcia et al. 1999, Buttow et al. 2003, Carvalho etal. 2006). There is a possibility that the benzalkonium chloride (CB) causes intrinsic denervation of the intestine (Oliveira et al. 1990, Hanani et al. 2003, Laranjeira et al. 2011, Fujimura et al. 2016, Yu et al. 2016) and possibly has a clinical application in situations where denervation is a recommended for specific segments. An example is the denervation of the remaining ileum in Short Bowel Syndrome in experimental rats, in which it has a beneficial effect on animal clinical parameters, therefore constituting a possibility of treatment in the future
(Garcia et al. 1999, Carvalho et al. 2006). However, there is a need to improve the techniques of application of CB, because in the existing model, the application in the intestine serosa through laparotomy can lead to peritonitis and formation of bands, which lead to a high mortality.

The results obtained in this study demonstrated the feasibility and effectiveness of intramural application of CB to get the digestive tube denervation, with a view to greater precision of this method of application of $\mathrm{CB}$, through intramural applications. It was also possible to deepen the knowledge about the evolution of neuronal injury caused in this process, through histopathological analysis and immunohistochemistry by immunolabeling histones specific gamma-H2AX (H2AX) that assesses the presence of oxidative nuclear stress injuries (Berra et al. 2006, Redon et al. 2012) and Caspase-3, which detects apoptose (Terzian et al. 2007, El-Aal et al. 2016) of the myenterics neurons.

\section{MATERIALS AND METHODS}

It was used 40 wistar rats (Rattus norvegicus albinus variation), male, weighting from 350 to $450 \mathrm{~g}$, taken from the vivarium of the Faculty of Medicine of Ribeirão Preto, University of São Paulo (FMRP-USP). The 40 wistar rats were randomly divided into two groups, GC (Control Group) and GB (Benzalkonium Group), containing 20 animals each. The groups were divided evenly into four sub-groups according to the time: 24, 48 hours, 30 and 90 days, containing five animals each, being GC1 GC2 GC3 GC4, respectively, for the control group and GB1 GB2, GB3 GB4 with same times for the Benzalkonium Group.

The GB rats were submitted to intramural microinjections of benzalkonium chloride $0.3 \%$ in the ileal segment. For this, median ventral laparotomy was performed with subsequent exposure and exteriorization of the ileum. Intramural microinjections were applied in $5 \mathrm{~cm}$ of the ileal segment cranial to the ileum cecum-colic valve, using $1 \mathrm{~mL}$ syringe with size needle of $13 \mathrm{~mm} \times 0.45 \mathrm{~mm} .1 \mathrm{~mL}$ of CB $0.3 \%$ was applied and distributed in each microinjections Fishbone-shaped (Fig.1A) totalizing 10 microinjections, these applications were distributed in five microinjections on the right side and five on the left side of the ileum, from the antimesenteric toward the mesenteric border (Fig.1A,B). After this procedure, the

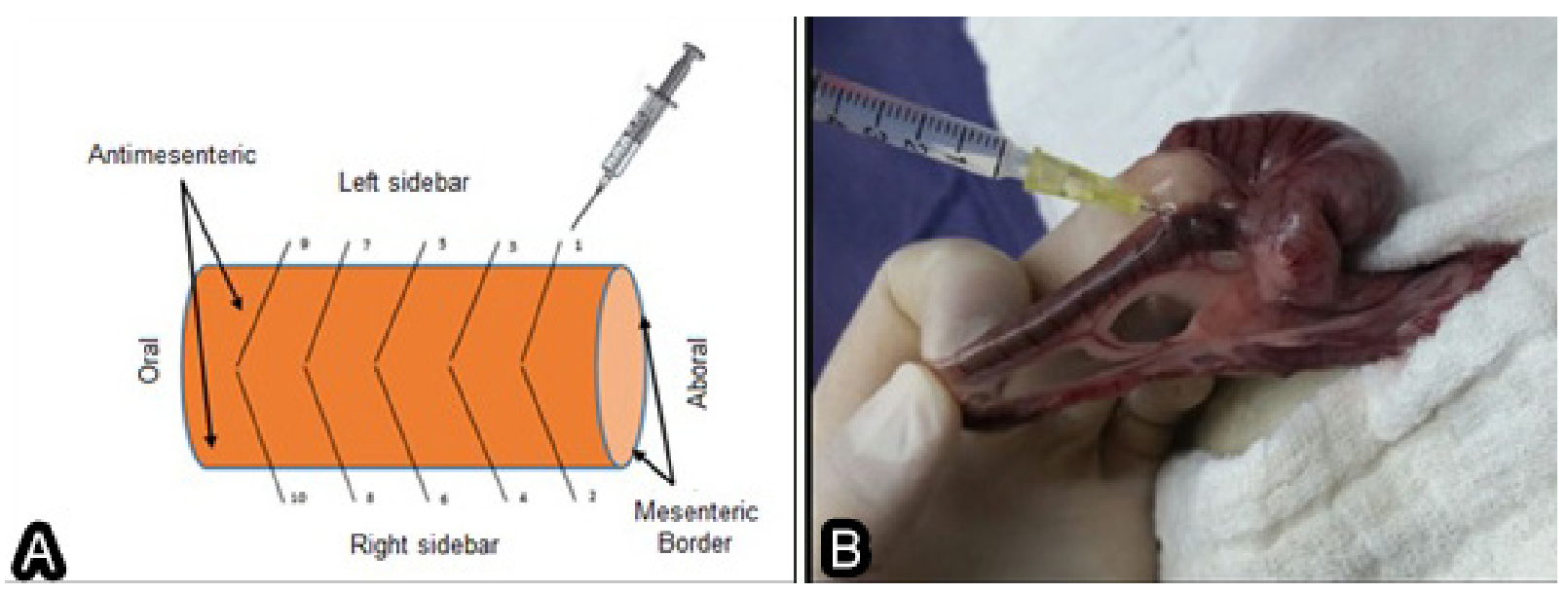

Fig.1. (A) Schematic drawing of microinjections intramural applied in rat ileal segment in the dorso-ventral aspect. Held ten microinjections Fishbone-shaped distributed in five microinjections in right side and five on the left side of the ileum, from antimesenteric edge toward the mesenteric border. (B) Surgical procedure for realization of microinjections intramural of sterile saline or benzalkonium hydrochloride in wistar rats. Exposure and exteriorization of ileal segment, microinjections in muscle layer in $5 \mathrm{~cm}$ aborais íleal segment. 
ileal segment was submitted to washing with profuse application of saline $0.9 \%$. The viscera were reintroduced into the abdomen and the abdominal wall rebuilt through two plans suture. The rats in GC were submitted to the same procedure of GB, except for the application of saline solution $0.9 \%$.

The animals of the GC1 and GB 1 were euthanized 24 hours postoperatively, the GC2 and GB2 48 hours postoperatively, the GC3 and GB3 with 30 days and finally, GC4 and GB4 with 90 days postoperatively. The ileal segment was collected and fixed in formalin (10\%) for histopathological and immunohistochemical study with Giemsa staining.

Histopathological evaluation. After routine histological processing and staining for hematoxylin and eosin (HE), histopathological evaluation was performed of the ileal wall and the population of mienteric neurons were counted in objective of $40 \mathrm{x}$ and rated by histological cut.

Immuno-istochemical analyses. Immunolabeling evalution of histones gamma-H2AX ( $\mathrm{H} 2 \mathrm{AX})$ and Caspase- 3 was made in objective of $40 x$ taking the entire length of each cut for evaluation. For evaluation of cells positively stained for $\mathrm{H} 2 \mathrm{AX}$ and occurrence of oxidative stress, assessed the nucleus, since the histone acts as a marker of breaks on dual tape DNA (Berra et al. 2006, Redon et al. 2012). For evaluation of cells positively stained for Caspase-3 and occurrence of apoptosis, assessed the cellular cytoplasm (Terzian et al. 2007).

Statistical analysis. The results of the neuronal counts will be presented as mean \pm standard deviation. The comparison of the count of the number of myenteric neurons made during the histopathological analysis between the GA and GB were performed by using the non-parametric Student $t$ test with significance level established at $\mathrm{p}<0.05$. The analysis of immunolabeling of $\mathrm{H} 2 \mathrm{AX}$ and Caspase- 3 was made in descriptive form.

Ethics. The project was submitted and approved by the Commission of ethics in the use of Animals (CEUA), College of Agricultural Sciences and Veterinary (FCAV), Universidade Estadual Paulista "Júlio de Mesquita Filho" (Unesp), Campus de Jaboticabal, SP, executed according to the standards required by CONCEA (National Council for Animal Experimentation control). Protocol no. 18,937/16.

\section{RESULTS}

Technical assessment of implementation of CB intramural

Confirmation of the effectiveness of microinjections applied intramural, was accomplished through histopathologic study of the ileal wall. In all rats (both the GC as in GB) it was possible to observe the presence of injury hitting part of the internal muscle layer and part of the submucosal layer (asterisk) in 24 hours (Fig.2B).

\section{Neuronal analysis-counting the number of myenteric neurons}

To assess the effectiveness of microinjections of $0.3 \%$ in $\mathrm{CB}$ to induce intrinsic denervation of the ileal wall, the population of myenteric neurons of ileum wall was estimated through neuronal count. The results were expressed as number of myenteric neurons by histological cut.

There was no significant difference in neuronal count between the GC1 and GB1 (24 hours). However, there was a reduction in the number of neurons in the groups treated GB2 (48 hours), (30 days) and GB3 GB4 (90 days) when compared to the respective Control Groups $(\mathrm{P}<0.05)$. Of these, GB3 and GB4 presented the lowest number of neurons in clumps, in which exposure to CB was prolonged (30 and 90 days respectively) ( $\mathrm{p}<0.0001)$ (Fig. 3).

\section{Analysis of the mechanism of action of neuronal injury caused by $\mathrm{CB}$}

The evaluation of myenteric neuron injury by oxidative stress and apoptosis was analyzed by means of histopathological and immunohistochemical study. In the histopathological analysis
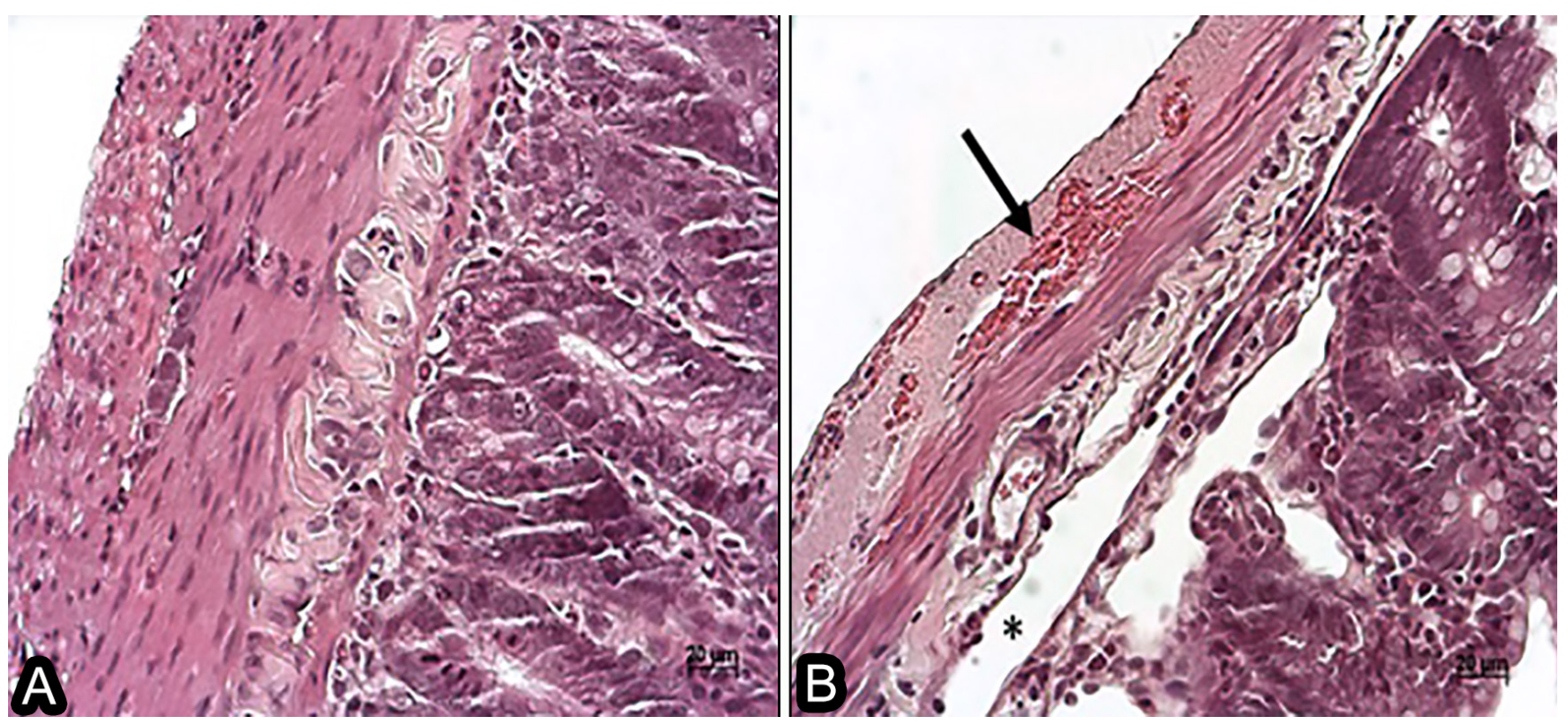

Fig.2. Ileal segment of wistar rat. (A) Normal rat ileal segment. Giemsa stain, obj.40x. (B) Injury that affects part of the submucosal layer and part of the internal muscle layer diverticulum after 24 hours (asterisk). Intraparietal hemorrhage, characterized by large numbers of red blood cells (arrow). Significance level p<0.05 (asterisk). Giemsa stain, obj.40x. 

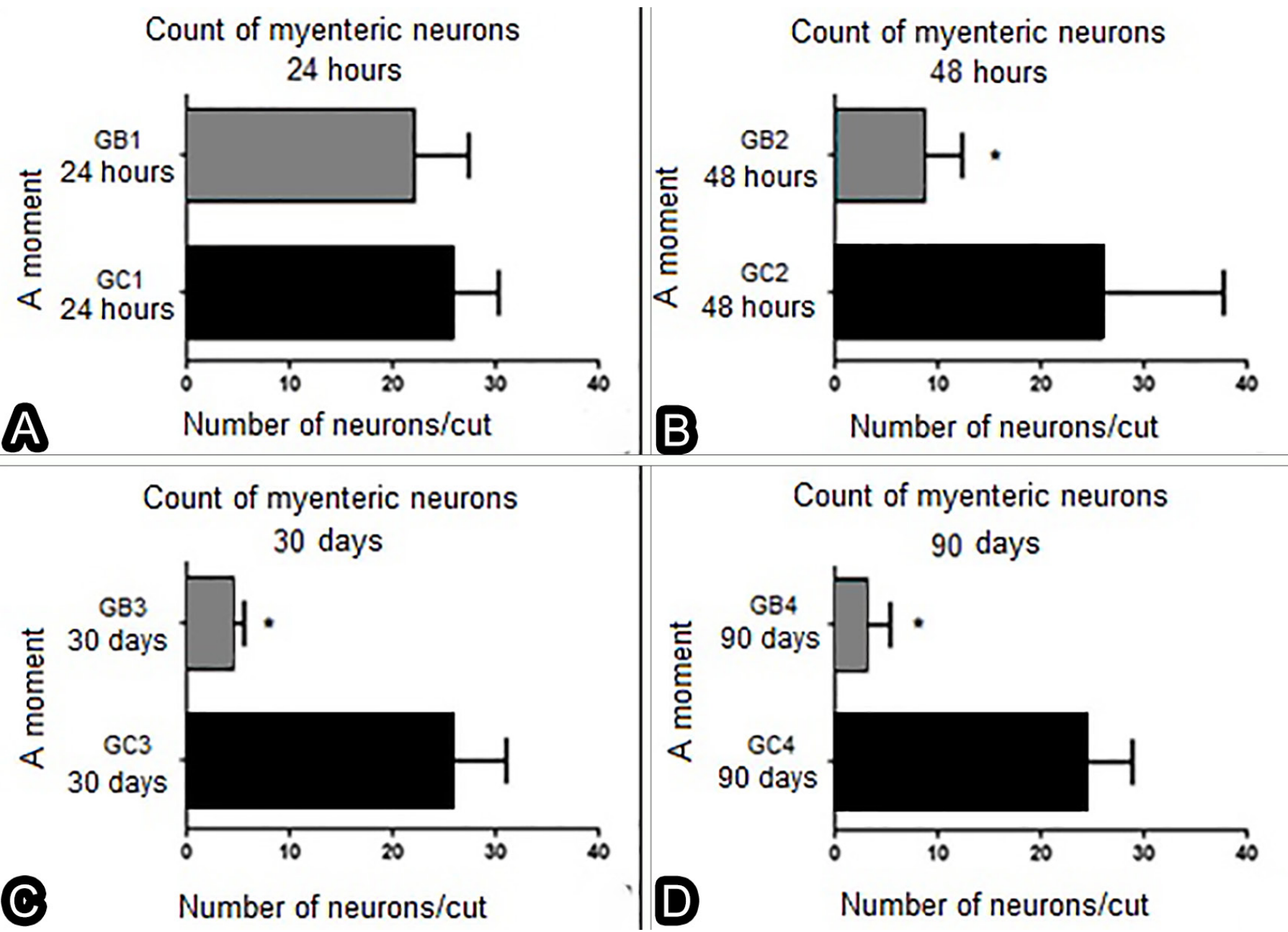

Fig.3. Comparison of myenteric neuronal countin different moments between the GC (Control Group) and GB (Benzalkonium Group).

(A) Comparison between the groups GC1 and GB1 in 24 hours. (B) Comparison between the groups GB2 and GC2 in 48 hours.

(C) Comparison between the groups GB3 and GC3 in 30 days. (D) Comparison between the groups GC4 and GB4 in 90 days.

there were no significant changes in scores and morphological changes in neurons of the myenteic Control Groups (Fig. 4A). In GB1 (24 hours) myenteric neurons exihibited cytoplasmic vacuolation, indicating the beginning of the apoptotic process (Fig. 4B). In GB2 (48 hours) apoptotic cells and inflammatory were numerous (Fig.4C). In GB3 (30 days) showed in Figure 4D, and GB4 (90 days) apoptosis cells were not observed. In these (GB3 and GB4) rarefaction of myenteric neurons was observed in areas close to the traumatic injuries of the mucosa. However, it was possible to observe the presence of GB4 hypertrophied residual myenteric neurons (Fig.4E), possibly as a mechanism of neuroplasticity, the compensatory neuronal loss caused by chemical denervation.

In the Immunohistochemistry analysis, immunolabeling of $\mathrm{H} 2 \mathrm{AX}$ was observed from 24 hours (GB1) (Fig.5A) after application of the $\mathrm{CB}$ in the ileal segment, extending for a period of 48 hours (GB2) (Table 1, Fig.5B).

\section{DISCUSSION}

The myenteric nerve block using CB is widely accepted and used in experimental studies by means of technique in which the application is done locally on the serosa of the viscera, using a
Table 1. Expression of positivity of the specific immunomarkers for evaluation of oxidative stress and apoptosis in ileum from wistar rats submitted to ileal myenteric denervation with benzalkonium chloride $0.3 \%$ by means of microinjections

\begin{tabular}{|c|c|c|c|}
\hline \multirow{2}{*}{ Moment } & \multirow{2}{*}{ Group } & \multicolumn{2}{|c|}{ Positivity } \\
\hline & & $\mathrm{H} 2 \mathrm{AX}$ & CASPASE-3 \\
\hline 24 hours & GB1 & $* * *$ & - \\
\hline 48 hours & GB2 & $* * *$ & $* * *$ \\
\hline 30 days & GB3 & - & - \\
\hline 90 days & GB4 & - & - \\
\hline
\end{tabular}

gauze soaked with the substance and applied on the intestinal segment for a period of 30 minutes, followed by profuse lavage with saline 0.9\% (Zucoloto et al. 1997, Hanani et al. 2003, Laranjeira et al. 2011, Yu et al. 2016). This technique has been applied to produce an aganglionose model, suggesting that these treatment parameters are ideal for the production of hipoganglia (Oliveira et al. 1990, Yu et al. 2016). However, 

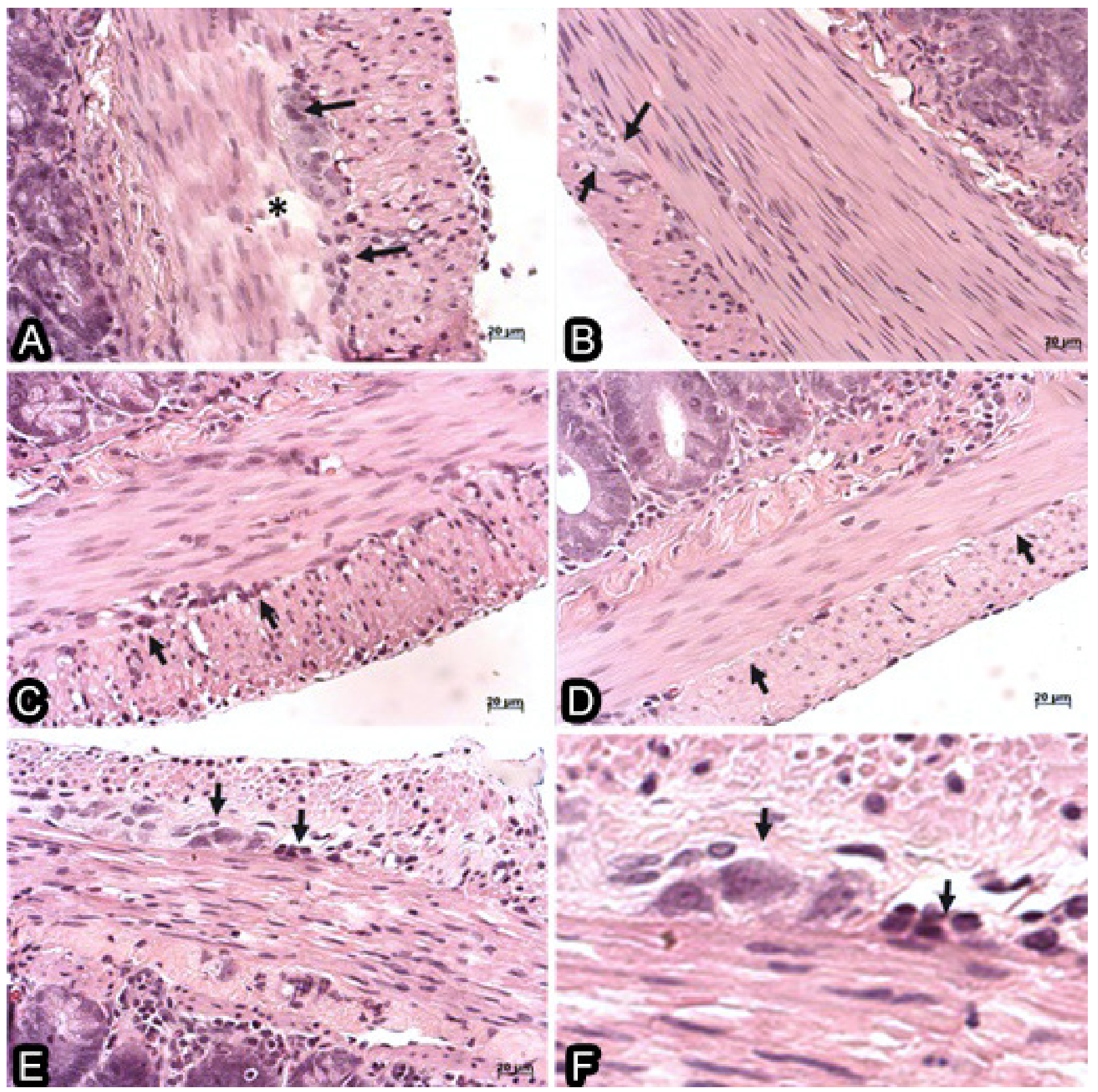

Fig.4. Ileal segment of wistar rat. (A) Control Group 24 hours, in the vicinity of traumatic lesions (asterisk), myenteric neurons with no morphometric changes (arrow). Giemsa stain, obj.40x. (B) GB1 (Benzalkonium Group), 24 hours, myenteric neurons with cytoplasmic vacuolation. Giemsa stain, obj.40x. (C) GB2, 48 hours, numerous apoptotic and inflammatory cells in the myenteric nodes (arrow). Giemsa stain, obj.40x. (D,E) GB3, 30 days, and GB4, 90 days, no cells in apoptosis are observed, important rarefaction of myenteric neurons in areas close to the traumatic injuries of the mucosa. Giemsa stain, obj.40x. (F) Hypertrophied residual myenteric neurons, can be viewed with nonspecific zoom at F (arrow). Giemsa stain, obj.40x.

this method of application is associated with complications such as peritonitis and small bowel adhesions near to the application site.

The toxicity of the CB is well known (Johnson 2018). It is known that low concentrations $(0.1$ to $0.5 \%)$ can cause irritation in the conjunctiva and mucosas (Gosselin et al. 1984) membranes (Leo \& Hollister 1991, Rowe et al. 2009, Papakrivou et al. 2017, Johnson 2018). Some authors (Marks \& Deleo 1992) recommend caution when using this substance in body cavities. Low concentrations of CB does not damage the 

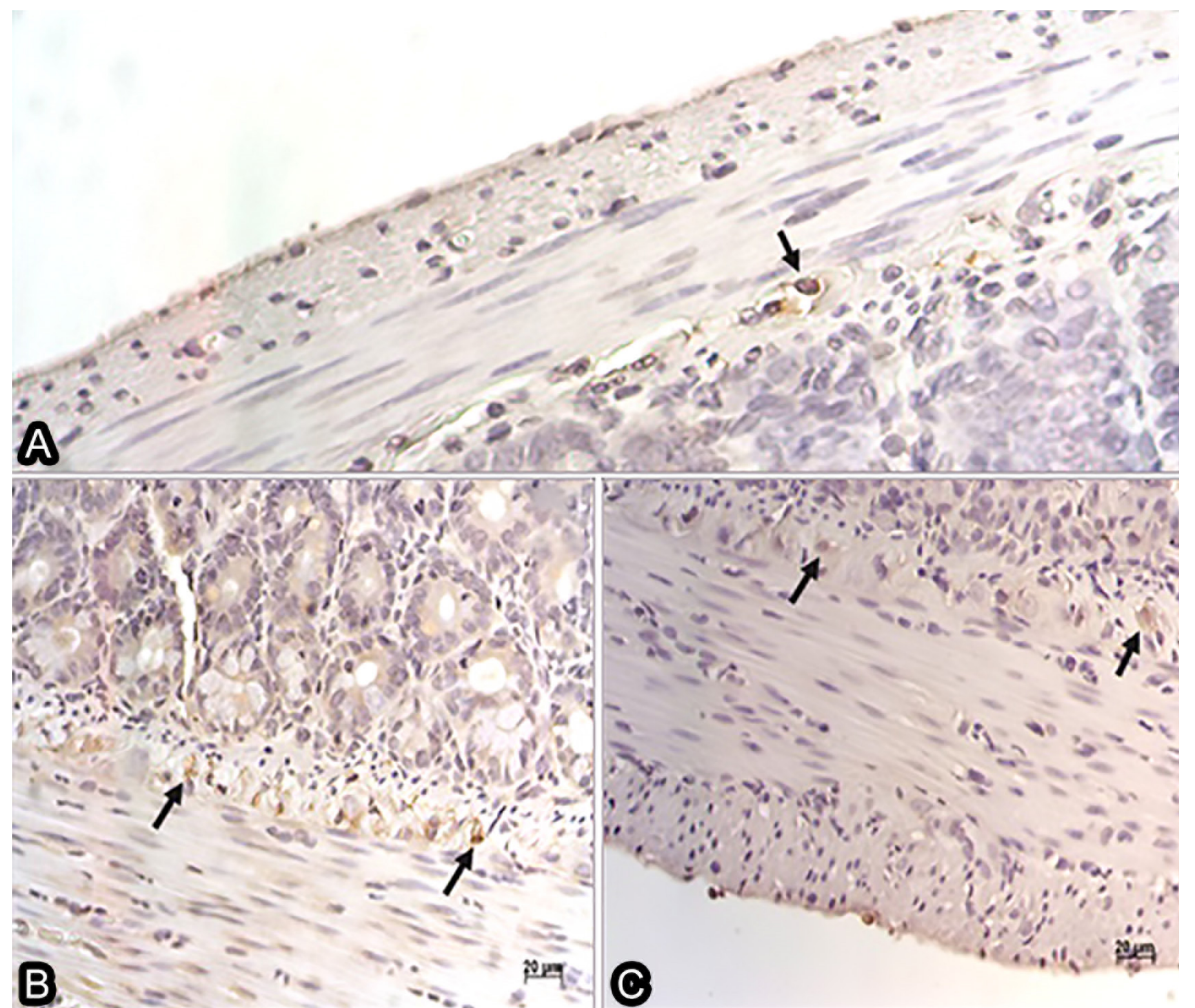

Fig.5. Immunohistochemistry of the diverticulum. (A) GB1 (Benzalkonium Group), 24 hours, and (B) GB2, 48 hours, intense nuclear H2AX expression in myenteric and submucosos neurons (arrows). (C) GB2, 48 hours, intense cytoplasmic marking of caspase-3 in myenteric and submucosos neurons (arrows). IHC, bar $=20 \mu \mathrm{m}$.

intestinal smooth muscle layer, while higher concentrations can break through the muscle layers and cause inflammation and intestinal perforation (Fox et al. 1983, Papakrivou et al. 2017). Despite the lack of updated literature about complications associated with the use of this technique, we noted in earlier studies, the occurrence of peritonitis followed by adhesions in some animals when treated with CB $0.3 \%$ via local applications in different intestinal segments. Thus, this study brings the possibility of minimizing the rates of adverse complications because of intramural microinjections, which does not lead to direct contact of $\mathrm{CB}$ with adjacent organs and abdominal cavity.

The reduction in the number of myenteric neurons found in this study corroborates the findings of other studies (Sato et al. 1978, Sakata et al. 1979, Garcia et al. 1999, Carvalho et al. 2006, Fujimura et al. 2016, Yu et al. 2016,
Belkind-Gerson et al. 2017) as the application of CB in serosa of the intestinal segment provoked myenteric denervation. In our study, it was possible to promote such change with the use of the technique of intramural microinjections, being effective in the myenteric denervation with minor complications, since peritonitis or small bowel adhesions were not observed.

In this study, we observed a decrease in the number of myenterics neurons over the different times, being more evident at 30 and 90 days after denervation, corroborating previous findings (Garcia et al. 1995, Zucoloto et al. 1997, Fujimura et al. 2016, Yu et al. 2016) and other authors, which supported these results indicating that the application of $2 \mathrm{~mm}$ solution of CB in the descending colon has reduced the number of neurons of the myenteric plexus in 10, 45 and 120 days after treatment compared to Control Groups. 
After histopathological and immunohistochemical analysis in this study, it was possible to see the selective CB effect to cause apoptosis of myenteric neurons, also noticed by other authors (Yu et al. 2016). This fact might be noticed by neuronal count reduced over time and by specific $\mathrm{H} 2 \mathrm{AX}$ immunolabeling and Caspase-3, corroborating the findings of other authors (Sato et al.1978), who demonstrated that this fact occurs due to its positive charge. It is believed that the membrane of the nerve is more negative than the muscle membrane and thus the nerve fibers would be more susceptible to damage by cationic agent. However, according to the same authors, evidence supporting the notion that enteric neurotoxicity induced by surfactants can be attributed more to the general properties of the surfactants than the charge specifically. Another study (Sakata et al. 1979) found that CB has a detrimental effect on cell membranes causing depolarization or affecting the sodium active transport. Once the negative charge is known to be higher in nervous tissue than in other tissues such as the smooth muscles, this mechanism may explain the selective denervation occurred.

The positive assessment of $\mathrm{H} 2 \mathrm{AX}$ detects oxidative stress, which may result in breaking the double stranded DNA and thus begin the apoptosis process, evaluated by immunolabeling Caspase-3 (Berra et al. 2006, Terzian et al. 2007, Cleaver 2011, Redon et al. 2012, Ghosal \& Chen 2013, El-Aal et al. 2016). For verification of the effectiveness of denervation by $\mathrm{CB}$, attesting the neuronal death and determination of the period in which this event occurred, was evaluated in this study, the presence of severe damage to genetic material, by means of immunohistochemical technique for detection of cells positively marked to $\mathrm{H} 2 \mathrm{AX}$, effective scorer in the presence of the double-stranded breaks of DNA (Sak \& Stuschke 2010, Cleaver 2011, Ghosal \& Chen 2013), characterizing the oxidative stress and the presence of neuronal apoptosis through immunolabeling of Caspase- 3 in different times (24, 48 hours, 30 and 90 days). We confirm once the CB served for inducing neuronal oxidative stress lions, followed by apoptosis.

\section{CONCLUSION}

The application of benzalkonium chloride (CB) at $0.3 \%$ by means of intramural microinjections in the ileal wall is able to induce intrinsic chemical denervation of the diverticulum of wistar rats, through neuronal injury by oxidative stress beginning at 24 hours and neuronal apoptosis 48 hours after application.

Conflict of interest statement.- The authors have no competing interests.

\section{REFERENCES}

Belkind-Gerson J., Graham H.K., Reynolds J., Hotta R., Nagy N., Cheng L., Kamionek M., Shi H.N., Aherne C.M. \& Goldstein A.M. 2017. Colitis promotes neuronal differentiation of Sox2+ and PLP1+ enteric cells. Scient. Reports 7(1):2525. $<$ http://dx.doi.org/10.1038/s41598-017-02890-y><PMid:28566702>

Berra C.M., Menck C.F.M. \& Di Mascio P. 2006. Estresse oxidativo, lesões no genoma e processos de sinalização no controle do ciclo celular. Química Nova 29(6):1340-1344.<http://dx.doi.org/10.1590/S0100-40422006000600032>

Buttow N.C., Zucoloto S., Espreafico E.M., Gama P. \& Alvares E.P. 2003. Substance P enhances neuronal area and epithelial cell proliferation after colon denervation in rats. Digest. Dis. Sci. 48(10):2069-2076. <http:// dx.doi.org/10.1023/A:1026103311800><PMid:14627357>
Carvalho C.E.V., Basile F.V.A., Vespúcio M.V.O., Iglesias A.C.G., Gava N.F. \& Garcia S.B. 2006. Efeitos da desnervação intrínseca do jejuno após enterectomia extensa na síndrome do intestino curto em ratos. Acta Cirúrg. Bras. 21(1):43-46.

Cleaver J.E. 2011. yH2AX: Biomarker of damage of functional participant in DNA repair "all the glitters is not gold". Photochem. Photobiol. 87(6):1230-1239. <http://dx.doi.org/10.1111/j.1751-1097.2011.00995.x><PMid:21883247>

El-Aal A.A., El-Gebaly N., Al-Antably A., Hassan M. \& El-Dardiry M. 2016. Post-immunization immunohistochemical expression of Caspase 3 and p53 apoptotic markers in experimental hydatidosis. Revta Bras. Parasitol. 25(3):333-340. <http://dx.doi.org/10.1590/S1984-29612016058> $<$ PMid:27683842>

Fox D.A., Epstein M.L. \& Bass P.A.U.L. 1983. Surfactants selectively ablate enteric neurons of the rat jejunum. J. Pharmacol. Exp. Therap. 227(2):538544. <PMid:6195330>

Fujimura T., Shibata S., Shimojima N., Morikawa Y., Okano H. \& Kuroda H. 2016. Fluorescence visualization of the enteric nervous network in a chemically induced aganglionosis model. Plos One 11(3):150-579. <http://dx.doi. org/10.1371/journal.pone.0150579><PMid:26943905>

Garcia S.B., Pinto L.Z., Zucoloto S. \& Oliveira J.S.M. 1995. Experimental megaileum. Res. Exp. Med. 195(4):249-253. <http://dx.doi.org/10.1007/ BF02576795><PMid:8525076>

Garcia S.B., Kawasaky M.C., Silva J.C., Garcia-Rodrigues A.C., Borelli-Bovo T.J., Iglesias A.C. \& Zucoloto S. 1999. Intrinsic myenteric denervation: a new model to increase the intestinal absortive surface in short-bowel syndrome. J. Surg. Res. 85(2):200-203.<http://dx.doi.org/10.1006/jsre.1999.5670> <PMid:10423319>

Ghosal G. \& Chen J. 2013. DNA demage tolerance: a double-edged sword gurading the genome. Translational Cancer Res. 2(3):107-129. <PMid:24058901>

Gosselin R.E., Smith R.P. \& Hodge H.C. 1984. Clinical Toxicology of Commercial Products. 5th ed. Williams and Wilkins, Philadelphia.

Hanani M., Ledder O., Yutkin V., Abu-Dalu R., Huang T., Härtig W., Vannucchi M. \& Faussone-Pellegrini M. 2003. Regeneration of myenteric plexus in the mouse colon after experimental denervation with benzalkonium chloride. J. Comp. Neurol. 462(3):315-327. <http://dx.doi.org/10.1002/ cne.10721><PMid:12794735>

Johnson NF. 2018. Pulmonary toxicity of benzalkonium chloride. J. Aerosol Med. Pulmonary Drug Delivery 31(1):1-17. <http://dx.doi.org/10.1089/ jamp.2017.1390><PMid:28683210>

Laranjeira C., Sandgren K., Kessaris N., Richardson W., Potocnik A., Vanden Berghe P. \& Pachnis V. 2011. Glial cells in the mouse enteric nervous system can undergo neurogenesis in response to injury. J. Clin. Invest. 121(9):34123424. <http://dx.doi.org/10.1172/JCI58200> <PMid:21865647>

Leo E., Hollister M.D. 1991. Drug evaluations annual 1991. J. AMA 266(3):424.

Marks J.G. \& Deleo V.A. 1992. Contact and Occupational Dermatology. Mosby Year Book, Missouri, p.30-49.

Oliveira J., Llorach-Velludo M. \& Sales-Neto V. 1990. Megacolon in rats. Digestion 45(3):166-171. <http://dx.doi.org/10.1159/000200239> $<$ PMid:2373271>

Papakrivou E., Makris D., Manoulakas E., Mitroudi M., Tepetes K., Papazoglou K. \& Zakynthinos E. 2017. Intra-abdominal hypertension causes bacterial growth in lungs: an animal study. BioMed Res. Int. 2017:1-7. <http://dx.doi org/10.1155/2017/4601348><PMid:28357400>

Redon C.E., Weyemi U., Parekh P.R., Huang D., Burrell A.S. \& Bonner W.M. 2012 $\mathrm{c}-\mathrm{H} 2 \mathrm{AX}$ and other histone posttranslational modifications in the clinic. Biochim. Biophys. Acta 1819(7):743-756. <http://dx.doi.org/10.1016/j. bbagrm.2012.02.021><PMid:22430255>

Rowe R.C., Sheskey P.J. \& Quinn M.E. 2009. Handbook of Pharmaceutical Excipients. 6th ed. Pharmaceutical Press, London, p.209-285. 
Sak A. \& Stuschke M. 2010. Use of $\gamma \mathrm{H} 2 \mathrm{AX}$ and other biomarkers of doublestrand breaks during radiotherapy. Semin. Radiation Oncol. 20(4):223-231. <http://dx.doi.org/10.1016/j.semradonc.2010.05.004><PMid:20832014>

Sakata K., Kunieda T., Furuta T. \& Sato A. 1979. Selective destruction of intestinal nervous elements by local application of benzalkonium chloride solution in the rat. Experientia 35(12):1611-1613. <http://dx.doi.org/10.1007/ BF01953222><PMid:520469>

Sato A., Yamamoto M., Imamura K., Kashiki Y., Kunieda T. \& Sakata K. 1978. 70 Pathophysiology of aganglionic colon anal anorectum: na experimental study of aganglionosis produced by a new method in the rat. J. Pediatr. Surg. 13(4):399-435. <http://dx.doi.org/10.1016/S0022-3468(78)804643> <PMid:682089>

Terzian A.C., Zuccari D.A.P.C., Pereira R.S., Pavam M.V., Ruiz C.M., Sueiro F.A.R. \& Coelho J. 2007. Avaliação da caspase-3 e Ki-67 como marcadores prognósticos nas neoplasias mamárias em cadelas. Braz. J. Vet. Res.
Anim. Sci. 44(2):96-102. <http://dx.doi.org/10.11606/issn.1678-4456. bjvras.2007.26647>

Yu H., Pan W., Wang H. \& Gao Y. 2016. A time-limited and partially reversible model of hypoganglionosis induced by benzalkonium chloride treatment. Neurochem. Res. 41(5):1138-1144. <http://dx.doi.org/10.1007/s11064015-1806-8> <PMid:26738989>

Zucoloto S., Silva J.C., Oliveira J.S.M. \& Muccillo G. 1991. The chronological relationship between the thickening of smooth muscle, epithelial cell proliferation and myenteric neural denervation in the rat jejunum. Cell Proliferation 24(1):15-20. <http://dx.doi.org/10.1111/j.1365-2184.1991. tb01507.x> <PMid:2009313>

Zucoloto S., de Deus D.A., Martins A.A., Muglia V.F., Kajiwara J.K. \& Garcia S.B. 1997. The relation between myenteric neuronal denervation, smooth muscle thickening and epithelial cell proliferation in the rat colon. Res. Exp. Med. 197(2):117-124. <http://dx.doi.org/10.1007/s004330050061> <PMid:9380951> 